\title{
Protective Effect of Ethanol and Potassium lodide on the Radiolysis of Indole-3-acetic Acid in Aqueous Solution
}

\author{
Hikoyuki Yamaguchi and Kyoko MiUra \\ Laboratory of Radiation Genetics, Faculty of Agriculture, \\ University of Tokyo, Tokyo, Japan \\ Received August 14, 1970
}

\begin{abstract}
Aqueous solutions of IAA in the presence or the absence of oxygen were irradiated with ${ }^{137} \mathrm{Cs}$ gamma radiation. The apparent oxygen effect on the loss of biological activity of IAA was not observed. As the concentration of IAA was increased, a smaller proportion of them was affected. Both ethanol and potassium iodide protected almost completely the radiolysis of IAA irradiated in aqueous solution. It was concluded that $\mathrm{OH}^{\cdot}$ radicals produced in the aqueous solution must produce harmful damage to IAA.
\end{abstract}

\section{Introduction}

There have been many reports dealing with the inhibitory effect of ionizing radiation on the growth of plant. It has been shown that the hormone auxin, identified as indole-3-acetic acid (IAA) in most cases, is synthesized in the stem apex, moves down through the stem and then promotes cell extension.

In 1935, Skoog $^{4)}$ reported that the effect of $\mathbf{X}$-irradiation on auxin and on the process of its formation was the major factor in the immediate inhibition of growth in the plant. Since the irradiation of aqueous solution of IAA resulted in an immediate loss of the activity took place only in the presence of oxygen, he pointed out that the mechanism of loss of activity was through the oxidation by peroxides or other strong oxidizing agents formed by irradiation in the solution. Skoog's result had been used subsequently by other workers to interpret various radiation responses on the basis of auxin radiosensitivity. Thus, Gordon and Weber ${ }^{1)}$ reinvestigated the destruction of IAA in aqueous solution by ionizing radiation. Their conclusion was that peroxides were probably not involved in auxin destroyed by radiation.

Hence, the mechanism of destruction of biologically active IAA produced by ionizing radiation in the solution remains to clarify. As a first experiment to determine the role of auxin in the immediate effect induced by radiation on the growth of higher plants, we decided to study the radiolysis of indole-3-acetic acid in aqueous solution. To obtain information on the role of water radicals in the radiation-induced destruction of IAA, we measured the protective effect of added compounds known to react with $\mathrm{OH}^{\text {. }}$.

\section{Materials and Methods}

Auxin, indole-3-acetic acid, was obtained. from Calbiochem, Los Angeles, Calif., USA. A given concentration of IAA was freshly prepared by dissolving the crystalline IAA with water distilled four times for each experiment.

Ordinary distilled water, acidified with concentrated sulfuric acid containing approximately $1 \mathrm{~g} \mathrm{KMnO}_{4}$ per litre, was redistilled. The distillate was made alkaline with sodium hydroxide and $0.1 \mathrm{~g} \mathrm{KMnO}_{4}$ was added per litre. This was then reflexed for 10 to 15 hours. Afterward, it was distilled twice in a Pyrex glassware.

A volume of $5 \mathrm{~m} l$ of IAA solution having various concentrations was placed in a series of small glass tubes with small capillary openings which were sealed with a flame without heating the solution before irradiation. The solutions were unbuffered ( $\mathrm{pH} 5$ to 6 ).

Nitrogen-saturated solutions were prepared as follows. The tubes containing the solutions were evacuated, and oxygen-free nitrogen gas was flushed and bubbled through capillary tubes into the solutions.

Inhibition of IAA activity was usually as-- 
sayed by the standard Avena curvature method. If IAA solutions were highly active, they were diluted with the distilled water to a concentration of 7 to 20 degree of Avena curvature which was the upper range of the concentrations directly measurable with the Avena method.

Ethanol and potassium iodide (Wako Pure Chemical Industries Ltd.) were of reagent grade and were used without further purification.

Solutions were irradiated at $25^{\circ} \mathrm{C}$ in the dark with gamma-rays from $4,000 \mathrm{Ci}{ }^{137} \mathrm{Cs}$ source. The dose rate was $440 \mathrm{R} / \mathrm{min}$ as determined by ferrous sulfate oxidation.

\section{Results}

Both 0.3 and $30 \mu \mathrm{g} / \mathrm{m} l$ solutions in air- and nitrogen-saturated water were irradiated with various doses of gamma rays. The activity of residual IAA concentration was measured by Avena coleoptile curvature. The biological activity of IAA found in the non-irradiated sample was always taken as 100 per cent (Fig. 1). In both solutions, residual IAA activity decreased exponentially with increasing doses.

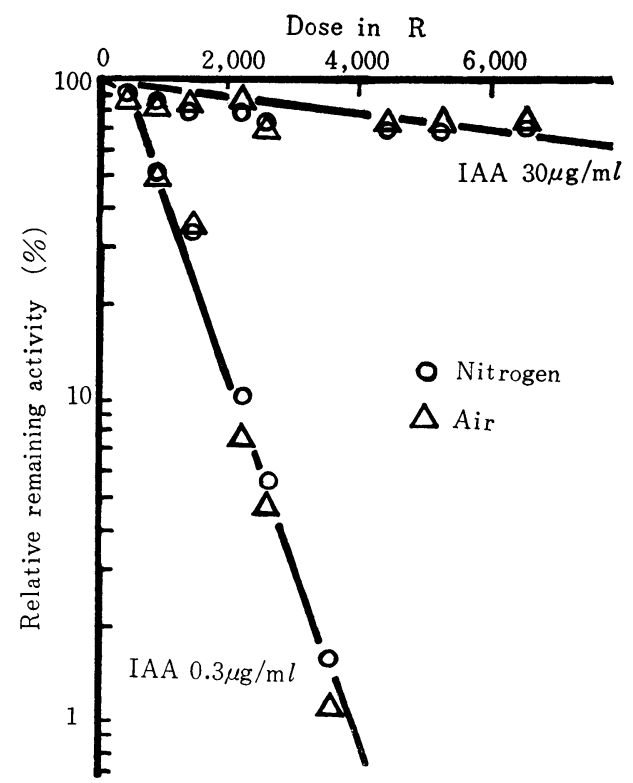

Fig. 1 Residual concentrations of IAA as a function* of gamma-ray dose at two initial concentrations. O, Aerated, $\triangle$, Nitrogen-saturated.

Concerning the loss of activity, a remarkable difference was observed between two, concentrated and dilute, aqueous solutions. In Fig. 1, it is clear that the difference of curve between air- and nitrogen-saturated solutions was not appreciable. Therefore, nitrogen-saturated aqueous solution was used throughout the subsequent experiments. $G$ value for the destruction of IAA was 11.4 in a concentrated solution and was 2.2 in a dilute solution.

Every tube containing various concentrations of IAA were treated with $5,280 \mathrm{R}$ of gamma rays. The results are shown in Fig. 2. As expected from Fig. 1, the remaining activities decreased with dilution of the solution. If the initial concentration beyond $5 \mu \mathrm{g} / \mathrm{m} l$, however, the percentage stayed constant.

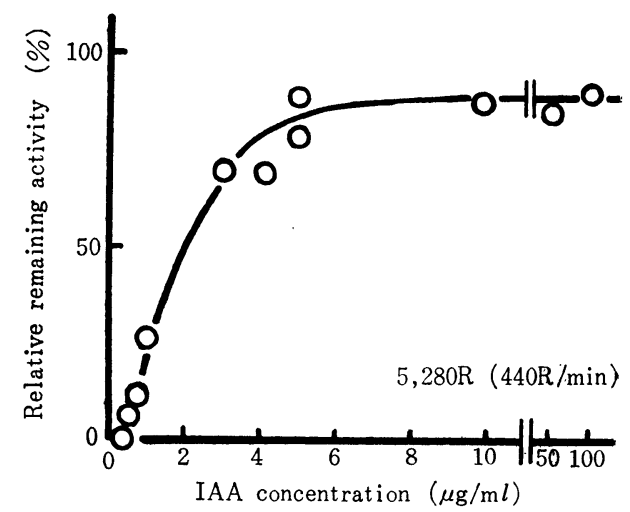

Fig. 2 Residual concentrations obtained by irradiation of various initial IAA concentrations.

Ethanol and potassium iodide are known as the effective scavengers of $\mathrm{OH}^{\cdot}$ radical produced by radiation in the solution. An identical pair of tubes containing a given concentration $(0.3 \mu \mathrm{g} / \mathrm{m} l)$ of IAA and various concentrations of ethanol or potassium iodide was prepared. One was treated with $1,320 \mathrm{R}$ of gamma rays and the other was untreated. As shown in Fig. 3(A), ethanol reduced the destruction yield of IAA, and at $1 \times 10^{-1} M$ its protective effect was almost complete. In the case of potassium iodide also, the obtained result was similar (Fig. 3(B)). At concentration of $4 \times 10^{-2} \mathrm{M}$, the protective effect of potassium iodide was found to be about $100 \%$.

\section{Discussion}

Due to the high content of oxygen-saturat- 


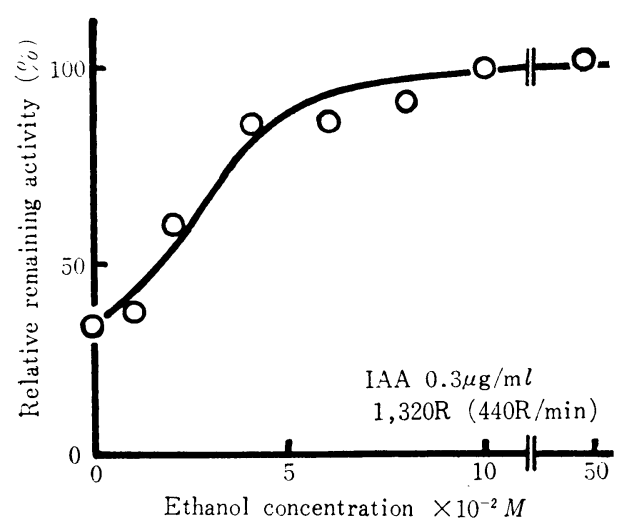

(A)

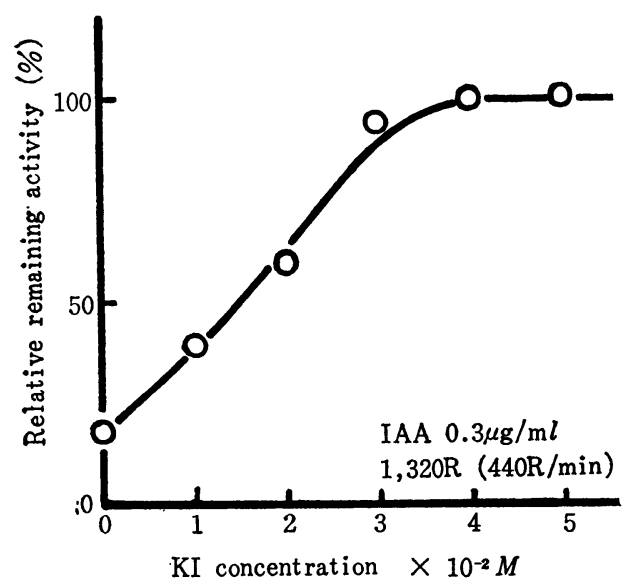

(B)

Fig. 3 Effect of ethanol (A) and potassium iodide (B) on IAA destruction by gamma-rays.

ed water, about 90 per cent, in the living cell, the effect of ionizing radiations in aqueous solutions saturated with oxygen would give a clue for the elucidation of the change produced in the cells by radiation.

The data presented in Fig. 1, show that IAA in aqueous solution was destroyed with gamma-rays whether oxygen was presented or not. In spite of the finding that high radiation dose gave rise to some destruction, Skoog ${ }^{4)}$ concluded that in the absence or in the very low concentrations of oxygen there was no immediate destruction of IAA. Gordon and Weber ${ }^{1)}$ reported that in comparison with the ionic yields of about 1 for IAA solutions in equilibrium with air, the yields dropped to between 0.5 and 0.3 in the absence of air. In our experiment, the residual IAA concentrations irradiated in the presence of nitrogen gas was 10 per cent more than in air-saturated solution. In spite of that the activity of nonirradiated sample in the presence of nitrogen gas was 10 per cent higher than that in the presence of air, percentage of the loss of IAA activity compared to each non-irradiated control was almost the same in both conditions.

The total amount of IAA destroyed by a given dose was greater in the high concentrated solutions, but the percentage of IAA destruction increased with the dilution of the solution. A similar phenomena have been observed by Skoog $^{4}$. These results support the view that the loss of biological activity is indirect.

Since the water used in this experiment was distilled four times, the effect on the IAA molecules will be mediated through the radicals which are formed by the irradiation of water molecules. To determine which type of water radical is primarily responsible for the indirect effect in IAA destruction, the extent of protection was measured for two compounds known to react with $\mathrm{OH}^{-}$radical. As shown in Fig. 3, the almost complete protection of IAA destruction was observed in both $\mathrm{OH}^{\cdot}$ scavengers. The protection observed under anoxia could be explained solely on the basis of scavenging $\mathrm{OH}^{-}$radical. Thus, it is suggested that the indirect effect in IAA destruction is predominantly due to the action of $\mathrm{OH}^{\cdot}$ radicals.

Recently, it has been reported that in hydrated Escherichia coli free radical intermediates with properties similar to $\mathrm{OH}^{-}$are responsible for about half the total injuries ${ }^{2), 3}$. In Fig. 3, even with very good $\mathrm{OH}^{-}$scavengers very high concentrations are needed to obtain significant protection. It is reasonable to think that the protection due to a radical scavenger mechanism plays a minor role in the cells, and that $\mathrm{OH}^{\cdot}$ radicals could play a major role in the destruction of biologically active IAA.

\section{Acknowledgements}

The authors wish to express their appreciation to Mr. Hoshio Eguchi for his kindful technical help in gamma-irradiation. 


\section{References}

1) Gordon, S.A. and Weber, R.P.: Plant Physiol., 30, 200 (1955)

2) Johansen, I. and Howard-Flanders, P.:
Radiation Res., 24, 184 (1965)

3) Sanner, T. and Pihl, A.: Radiation Res., 37, 216 (1969)

4) Skoog, F.: J. Cellular Comp. Physiol., 7, 125 (1935)

要旨

\section{水溶液中のIAA 分子の放射線分解に対する \\ エタノールおよびKI の防護作用}

山口彦之, 三浦郷子

東京大学農学部放射線遗伝学教室

空気扰よびチッ素ガスの存在下でインドール酰酸 (IAA) の水溶液に ${ }^{137} \mathrm{Cs}$ のガンマ線を照射する とIAA の不活性化が打こる。酸素効果は認められなかった。IAAの濃度をましたときその不活性 化\%は減少した。ラジカル捕捉剤としてェタノールおよび KI を添加したときIAAの放射線分解 はほぼ完全に防護された。この結果, 反応機構としては OHラジカルによる不活性化が考えられる。 